\title{
Ecological Considerations in Real Estate Valuation
}

\author{
Agnieszka Bitner ${ }^{* *}$, Karol Król', Małgorzata Frosik', Mateusz Furczoń ${ }^{1}$ \\ 1 Faculty of Environmental Engineering and Land Surveying, Department of Agricultural Land Surveying, \\ Cadaster and Photogrammetry, University of Agriculture in Krakow, Balicka 253a, 30-198 Kraków, Poland \\ * Corresponding author's e-mail: rmbitner@cyf-kr.edu.pl
}

\begin{abstract}
This paper discusses the use of quantitative cartographic methods in the analysis of the undeveloped land properties located in the territory of the municipality of Zakopane. The municipality of Zakopane is a territory with specific ecological, climatic, natural and environmental characteristics. Approximately $60 \%$ of the county is covered by the Tatrzański National Park. It comprises many ecological landscape features such as parks, green spaces, and vantage points. The presence of these features increases the value of the property, but at the same time in many cases it creates barriers to the property management arising from the environmental protection. This area is frequently visited by tourists. The market analysis is the first stage of the real estate valuation process. It aims at the identification of the factors influencing the value of real property. The market analysis consists in determining the characteristics of the area where the real property is located and finding the features that have a significant influence on the value of the property. The results of market analysis, the availability and the amount of data may affect the selection of a valuation method. These data refer to the sale and purchase transactions of undeveloped land properties between January 2011 and December 2015. Quantitative cartographic methods were applied in order to demonstrate the importance of the reliable selection of representative real properties and its impact on the acquisition of the information about the real estate market under examination. These methods were also used to investigate the spatial distribution of the transactions and the unit prices of undeveloped land properties. The cartographic analysis was conducted using the ArcGIS software and maps available on the Tatrzański Municipal Geoportal.
\end{abstract}

Keywords: real estate market, thematic map, spatial analysis, Zakopane

\section{THE SPECIFICITY OF THE REAL ESTATE MARKET IN THE MUNICIPALITY OF ZAKOPANE}

Any local real estate market has its set of characteristics, which have a significant influence on the development of property prices [Stanek 2016, Kim 2019]. Identifying these characteristics is necessary for a thorough analysis of the local real estate market. Market research and market description is the first stage of the analysis. The more specific a real estate market is, the more features that are characteristic exclusively of this market it possesses. The next stage of the process is preparing a database, which will be analyzed using statistical or cartographic tools. When preparing the database for the analysis, one should define the criteria of eliminating the transaction properties from the original database including all transactions. These criteria depend on the market and property type. The elimination of transactions concluded under specific conditions should be exclusively based on these criteria.

The real estate market in Zakopane belongs to specific markets. It has specific ecological, climatic, natural and environmental considerations. Approximately $60 \%$ of the county is covered by the Tatrzański National Park. The Tatrzański National Park is one of Poland's most visited protected areas. It is visited by over 3 million tourists a year. [Miazek 2017]. The close proximity of the Tatrzański National Park in many cases creates barriers to the property management arising from the environmental protection. At the same time, the prices of real properties located in the vicinity of green spaces or of those with vantage 
points increase because of their higher landscape value [Kovacs 2012, Liebelt et al. 2019]. The importance of ecological considerations in the real property management was presented in detail in the publication on real estate valuation and environmental protection [Cymerman et al. 2000].

The market under study has also its specific ground conditions related to the topography of the area. The foundation of buildings on the steeply sloping grounds and on the grounds of a weak or heterogeneous structure requires additional solutions protecting the buildings against damage or construction accidents. Landform has a decisive influence on the spatial distribution of residential buildings. Residential buildings are built along the roads that were laid out earlier according to the landform, the roads run mainly along ridges. It is clearly visible in Figure 1. The residential areas are indicated in red, the district borders are in purple, whereas the border of the Tatrzański National Park from the south is indicated in green.

Moreover, the historical settings strongly linked to the climate benefits are relevant. Zakopane experienced the greatest prosperity in the second half of the 19th century owing to the popularization of its climate benefits by a physician Tytus Chalubiński, which eventually led to promoting Zakopane as a health resort in 1886 . He pioneered mountain climbing. He founded first schools, built roads, established banks and societies. It contributed to the development of Zakopane and Podhale. By the end of 1889, Zakopane had about 3000 inhabitants and its extraordinary "beauty of the Tatra mountains" attracted more and more artists who were passionate about the folk art and the music of Podhale. Ignacy Paderewski, Helena Modrzejewska and Stanislaw Witkiewicz may be mentioned among these [Białas and Budarka 1991]. It used to have and still has a significant influence on the type of housing development in the town.

Zakopane acquired the city rights in 1933. After the World War II, the town grew quite quickly, new investments were undertaken. Year by year, the number of tourists was increasingly greater ; however, with growing urbanization its therapeutic function was diminished, which was caused by the deterioration of its ecological status. In the middle of the 1970s, most of the health resorts were closed.

Today, Zakopane is constantly developing and it enjoys great popularity not only among the citizens of Poland, but also among foreign tourists. New apartments, hotels and guest houses are built; international sports and cultural events are organized. For historical reasons, a newly emerging building development must often take into account the specific architectural and urban conditions that are present on this market [PardoGarcia et al. 2018]. Unfortunately, urban development results in poor air quality. According to the article which presents the results of air quality testing in Poland [Kuchcik and Milewski 2018], Zakopane is one of the most polluted towns: "The alert level $100 \mu \mathrm{g} \cdot \mathrm{m}^{-3}$ for fine particulate matter concentration $\mathrm{PM}_{10}$, adopted in many European countries, is very often exceeded in Poland. If Poland assumed the same standards for permissible daily concentrations as those established in Italy $\left(75 \mu \mathrm{g} \cdot \mathrm{m}^{-3}\right)$, the number of days per year when

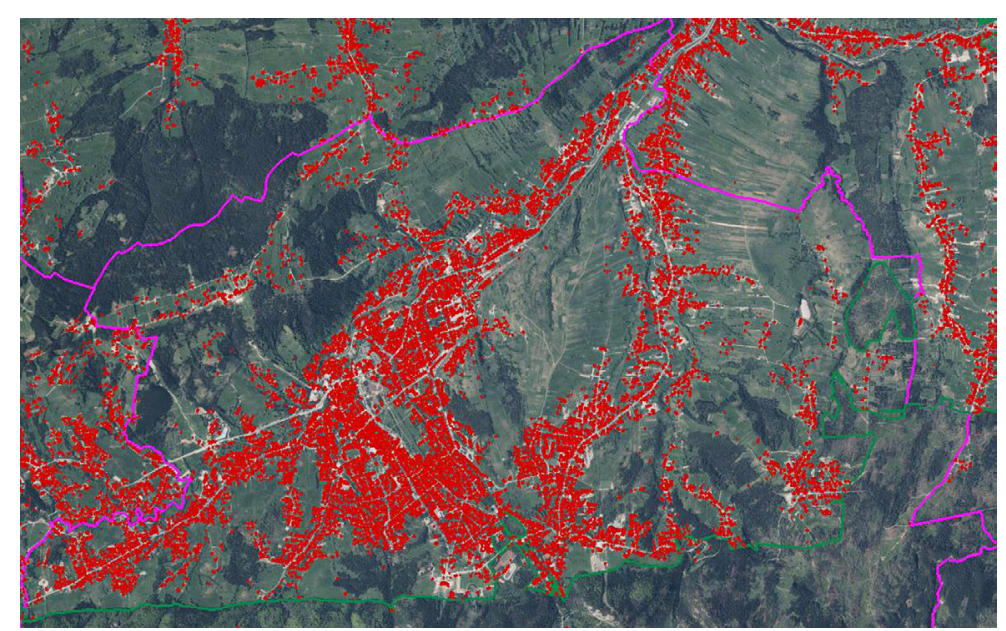

Fig. 1. The area of the Municipality of Zakopane reduced from the south by the area of the Tatrzański National Park

[http://tatrzanski.geoportal2.pl/map/www/mapa.php?CFGF=wms\&mylayers=+granice+OSM+] 
a smog alert should be announced (a high concentration of fine particulate matter in the air), would be 100 in Kraków, and about 30 in Lodz and Zakopane".

\section{DATA BASE ANALYSIS}

The data needed for the analysis were extracted from the County Office in Zakopane from the Register of Real Estate Prices and Values [Mika 2017]. The data contained three types of undeveloped land properties located within the Municipality of Zakopane. These include the agricultural single-use properties, agricultural multi-use properties and the properties intended for development other than farmstead. The analysis covered the area of the Municipality of Zakopane reduced by the area of the Tatrzański National Park because of the lack of transactions within the territory of the park.

The transaction data refer to the period between January 2011 and December 2015. During that period, 279 transactions involving undeveloped land were carried out. The dynamics of transactions in the respective years, together with the information about the total area of the land sold, is presented in Table 1.

Table 1 shows that the number of transactions in the years 2011, 2012, and 2015 remained at about the same level, and was close to average. In 2013, there was a significant decrease in the number of transactions, and in 2014 - a significant increase compared to the previous year. The total area of the land sold in the respective years was also similar; it achieved the lowest value in 2013 which was due to the smallest number of transactions in that year.

Table 1. The number of transactions per year together with the area of the land sold and the share of the land sold in the total municipal area for undeveloped land property

\begin{tabular}{|c|c|c|c|}
\hline Year & $\begin{array}{c}\text { Number of } \\
\text { transactions }\end{array}$ & $\begin{array}{c}\text { Area of the } \\
\text { land sold } \\
\text { [ha] }\end{array}$ & $\begin{array}{c}\text { Share in } \\
\text { the total } \\
\text { municipal } \\
\text { area [\%] }\end{array}$ \\
\hline 2015 & 55 & 6.45 & 19 \\
\hline 2014 & 77 & 7.82 & 23 \\
\hline 2013 & 41 & 4.72 & 14 \\
\hline 2012 & 50 & 8.84 & 26 \\
\hline 2011 & 56 & 5.62 & 18 \\
\hline average & 56 & 6.69 & 20 \\
\hline
\end{tabular}

Three types of undeveloped land property were traded. The agricultural multi-use properties were sold most often - see Table 2. Their market share is almost $44 \%$. The total surface area of these properties is almost half the surface area of all undeveloped land properties sold on the territory of the municipality.

\section{Using quantitative cartographic methods to analyze the market}

The following sources were used for the analysis:

- the register of real estate prices and values containing the information on transactions,

- the digital cadastral map from the County Office in Zakopane, owing to which the locations of specific transactions were identified. The analysis did not take into account the areas that are the part of the Tatrzański National Park, belonging to the municipality, because of the lack of transactions on that territory,

- maps dividing the town according to the current spatial development plans, received from the Municipal Office of Zakopane. The maps were modified (Fig. 2) in order to achieve a more transparent visualization of data.

A spatial analysis was conducted for the $\mathrm{Mu}$ nicipality of Zakopane divided into 22 areas: Antałówka, Bachledzki Wierch, Chłabówka, Cyrhla, Furmanowa, Gubałówka I, Gubałówka II, Harenda, Kamieniec, Kościeliska, Krzeptówki, Małe Żywczańskie, Nosal, Olcza, Pardałówka, Pod reglami, Polana Szymoszkowa, Skocznia, Śródmieście, Ustup, Wysówki, and Zamoyskiego. All maps, including those presenting the division into the areas (Fig. 2.), were created using the ArcGIS software designed by ESRI [Maguire et al. 2005].

Table 2. The number of transactions in the respective years together with the area of the land sold and the share of the land sold in the total municipal area for various types of undeveloped land property

\begin{tabular}{|l|c|c|c|}
\hline $\begin{array}{c}\text { Type of real } \\
\text { property }\end{array}$ & $\begin{array}{c}\text { Number of } \\
\text { transactions }\end{array}$ & $\begin{array}{c}\text { Market } \\
\text { share [\%] }\end{array}$ & $\begin{array}{c}\text { Area of the } \\
\text { land sold [ha] }\end{array}$ \\
\hline $\begin{array}{l}\text { Agricultural } \\
\text { multi-use }\end{array}$ & 123 & 44.09 & 16.71 \\
\hline $\begin{array}{l}\text { Agricultural } \\
\text { single-use }\end{array}$ & 69 & 24.73 & 8.31 \\
\hline $\begin{array}{l}\text { Intended for } \\
\text { development } \\
\text { other than } \\
\text { farmstead }\end{array}$ & 87 & 31.18 & 8.43 \\
\hline
\end{tabular}




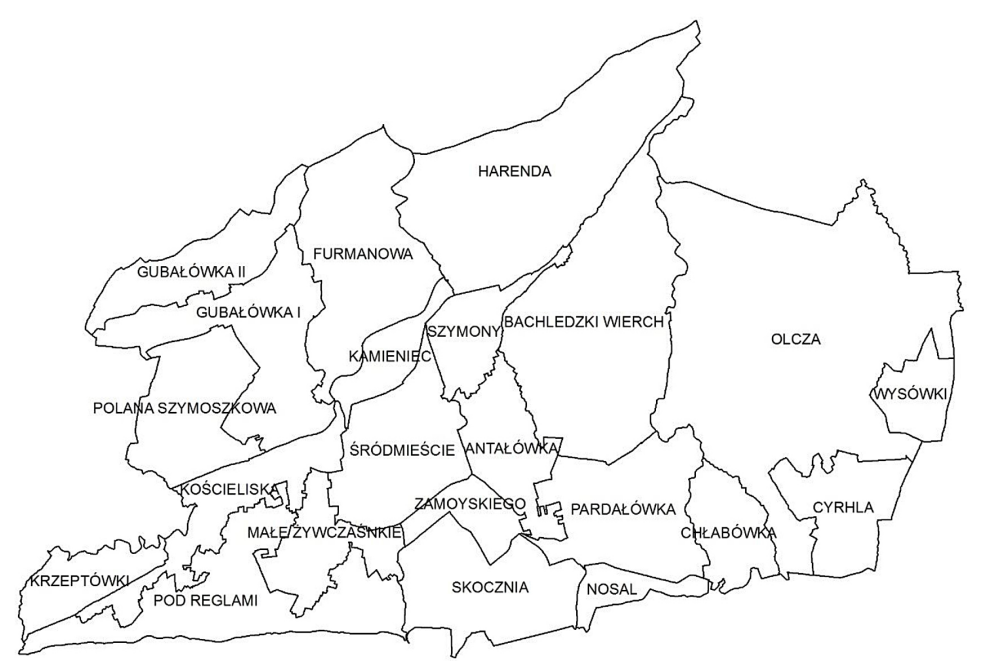

Fig. 2. The division of the Municipality of Zakopane into areas [based on the local spatial development plan]

Figures 3, 4 and 5 present the cartograms of transaction intensity in specific areas of the municipality during the period considered. The cartograms were made for each type of undeveloped land property.

The cartogram in figure 3 shows that the transactions of undeveloped agricultural singleuse properties took place in the peripheral parts of the town at a considerable distance from the center, because it is where the farmlands are situated. The greatest number of transactions took place is such areas as Harenda, Bachledzki Wierch, Pardałówka and Olcza.

The cartogram in figure 4 shows the intensity of transactions of undeveloped agricultural multi-use properties. Those transactions, as well as those of undeveloped agricultural single-use properties, took place mainly in the peripheral parts of the town, although many of them occurred closer to the center. The greatest number of transactions was made in such areas as Olcza and Bachledzki Wierch.

The cartogram in figure 5 shows the intensity of transactions of undeveloped land properties intended for development other than farmstead. This cartogram is significantly different from the other ones. The transactions of such properties were made mainly in the central area of the $\mathrm{Mu}$ nicipality of Zakopane. A large number of transactions can be also found in the area of Bachledzki Wierch, which is characterized by the greatest number of transactions of each type of undeveloped land property.

The map in figure 6 is a combination of quantitative methods: the diagram map shows the intensity of transactions concerning undeveloped

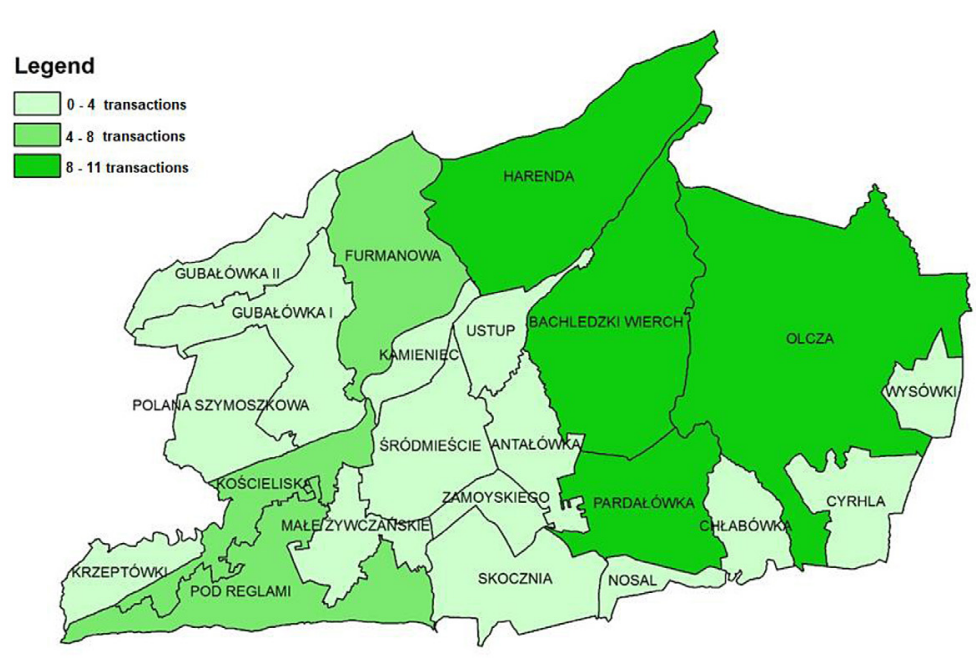

Fig. 3. The frequency of transactions of undeveloped agricultural single-use properties in the municipality of Zakopane in the years 2011-2015 


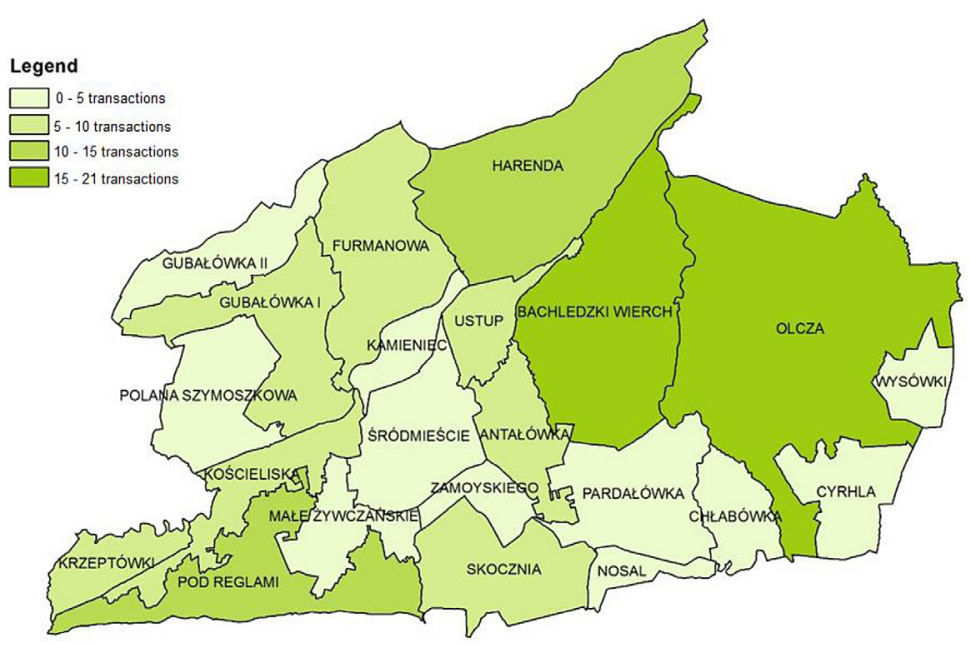

Fig. 4. The frequency of transactions of undeveloped agricultural multi-use properties in the Municipality of Zakopane in the years 2011-2015

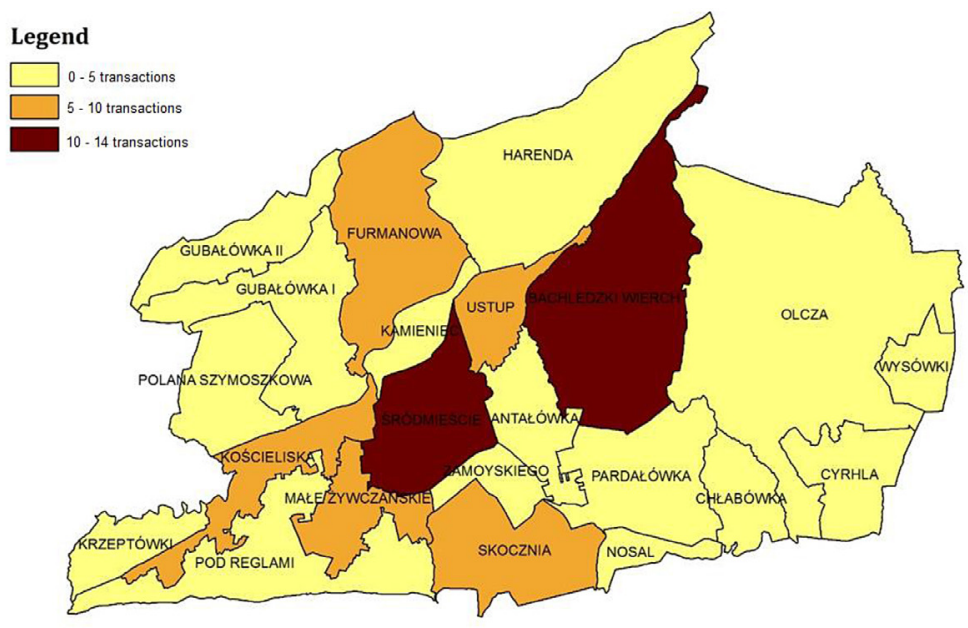

Fig. 5. The frequency of transactions of undeveloped land properties intended for development other than farmstead in the Municipality of Zakopane in the years 2011-2015

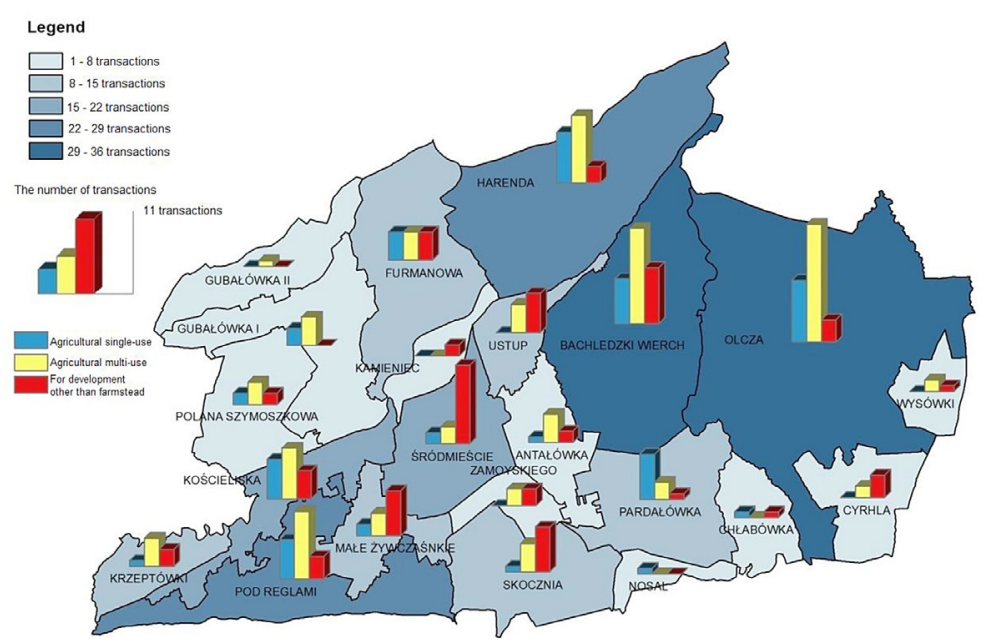

Fig. 6. The activity of the undeveloped land property market in the Municipality of Zakopane in the years 2011-2015 
land in the years 2011-2015 in specific areas, whereas the bar charts show the number of transactions depending on the type of land property in a given area.

On the basis of this diagram map, it can be concluded that the greatest number of transactions was made in the north-eastern and in the south-western parts of the municipality. The smallest number of transactions was made in the north-western part of the municipality in the areas such as Gubałówka I, Gubałówka II, Polana Szymoszkowa, and Kamieniec, in the south-eastern part of the municipality in the areas such as Wysówki, Cyrhla Chłabówka, and Nosal, and in the central part of the municipality in such areas as Antałówka and Zamoyskiego. The number of transactions in some parts of the municipality is influenced by the environmental characteristics of the parcels, which are typical only of this market, such as: the view from Gubałówka on the Tatra Mountains and the proximity to the Tatrzański National Park. The parcels in the locations that are very attractive in terms of views or natural features are not willingly sold by their owners, they are rather inherited. When a sale of such properties takes place, their prices are very high.

The predominant type of real estate sold in these parts of the municipality was agricultural multi-use land. In the central part, the transactions of properties intended for development other than farmstead were clearly predominant. When it comes to the agricultural single-use properties, they were the dominant type of properties sold only in the area of Pardałówka.

With the help of the map shown in figure 2 a simple diagram map was created (Fig. 7) showing the total surface area of the undeveloped land sold in various parts of the municipality of Zakopane. The largest area of the land sold was reported in the north-eastern part of the municipality in Olcza, Bachledzki Wierch and Furmanowa.

Further data analysis, which took into account the prices of real estate properties, was focused on selected properties. Data selection was necessary because the database contained the properties with special features. It was noted that in this local market, it is frequent to sell small shares in real estate properties. Such transactions relate mainly to the undeveloped agricultural multi-use properties and the land properties intended for development other than farmstead, where roads or forests are utilities. Zakopane has a very fragmented structure of the parcel surface area. Many transactions relate to the lands with the area not exceeding $180 \mathrm{~m}^{2}$. These parcels have irregular shapes. It could be assumed that they were sold mainly as a completion of a neighboring parcel, for example in order to make a better driveway, to widen a road; that is under special conditions. Therefore, during the selection process the transactions where the surface area was smaller than $180 \mathrm{~m}^{2}$, where the share in the real estate was smaller than $1 / 4$, and real estate properties that were roads or forests, were removed from the database. After the selection, the database finally includes 162 transactions.

The next stage of the analysis was to take into consideration the factors affecting the real estate prices that do not result from any real estate features. They are, for example, supply and demand changes taking place over some period of time or economic transformations. The impact of these factors is taken into account by determining the price index. Using this index, the time adjustment

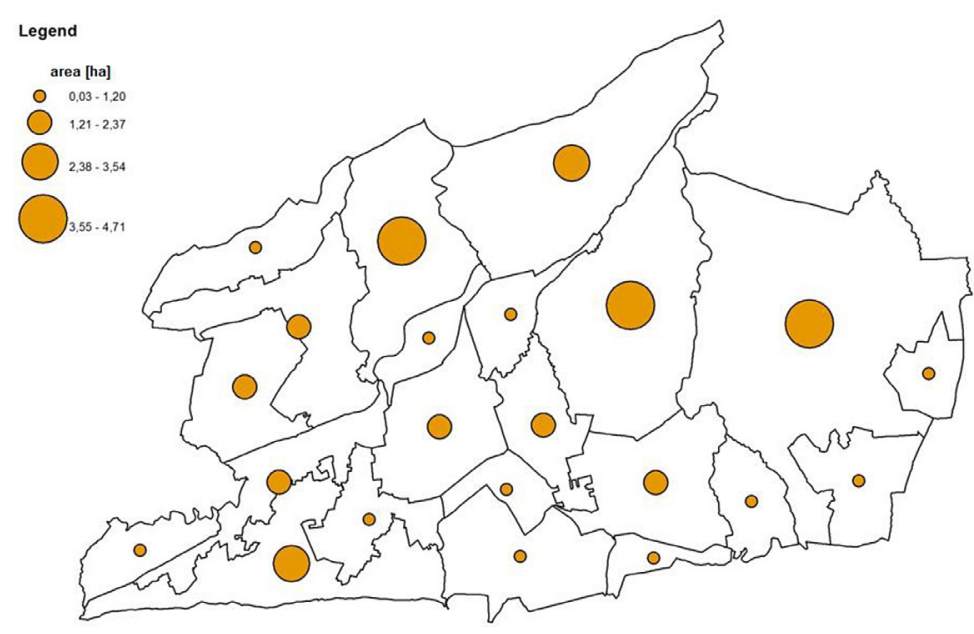

Fig. 7. The area of land sold in the years 2011-2015 in various parts of the Municipality of Zakopane 


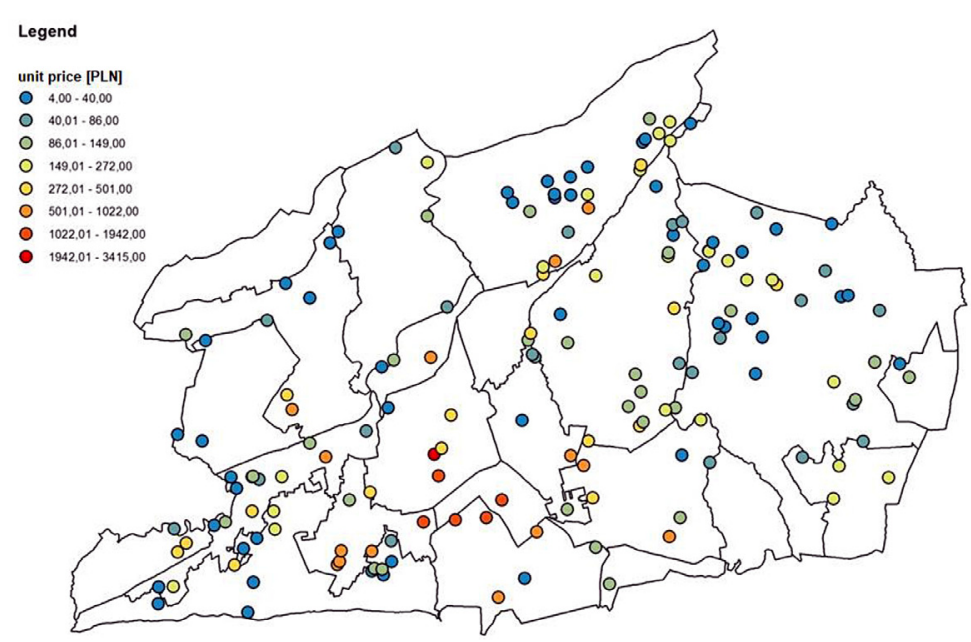

Fig. 8. The spatial distribution of transactions carried out in the years 2011-2015 together with the unit price levels of transaction prices of undeveloped land properties in the municipality of Zakopane

is done. There are several methods for determining price trends [Bitner 2011, Bitner 2015]. A linear regression model in the form $y=a+b x$ was used in the study. A simple linear regression coefficient is the price index sought. During the period considered, from 2011 to 2015 the price index was $-0.04 \%$ per month with a very large standard error of the estimate. The small value of the price index means that the market does not change significantly, and therefore this adjustment is not necessary.

In order to present the spatial distribution of transactions in the municipality of Zakopane, the dot method was used (Fig. 8). Dots denote the location of the real estate properties, which were the subjects of transactions. The colors of the dots are used to show the unit price levels in specific transactions.
The dot method of the cartographic presentation of transaction data provides the greatest amount of information about the market studied. By applying this method, one can obtain the information about the spatial distribution of transactions, and indicate the areas with the highest unit prices, which are the following: Śródmieście, Zamoyskiego, Skocznia, that is the town center of Zakopane. The lowest unit prices were noted in the areas located in the north-eastern part of the municipality.

In a market economy, it is hard to overestimate the usefulness of maps [Kraak 1998, Spallek 2011], maps of the distribution of land unit prices in particular [Całka i Bielecka 2014, Pochwatka 2017]. They contain the information useful in real estate management. These maps often show the relationship between the level of unit prices

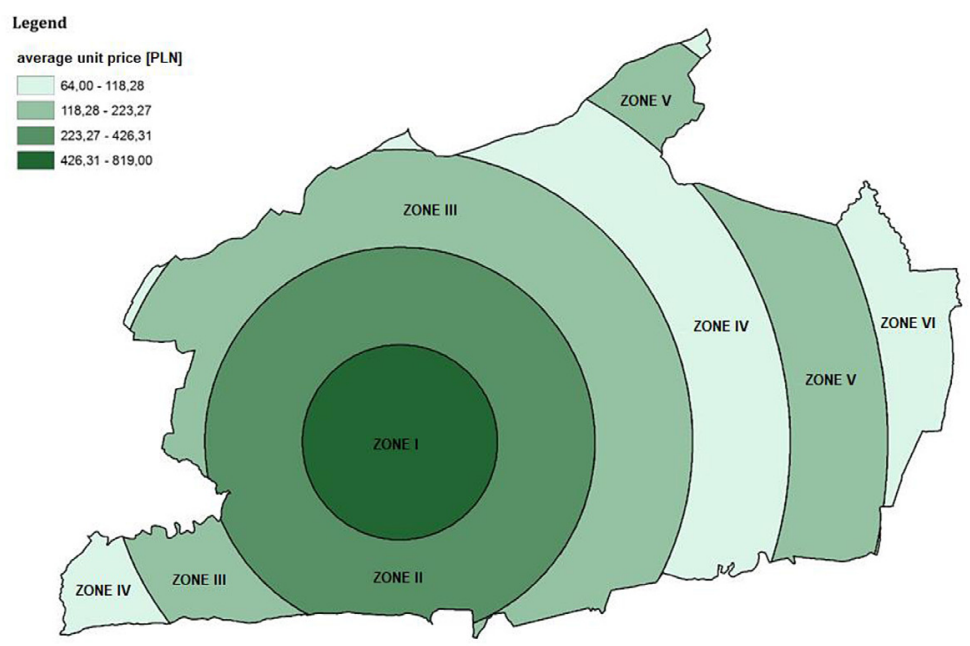

Fig. 9. The spatial distribution of average unit prices of undeveloped land properties in the Municipality of Zakopane depending on their distance from the center 
and the distance from characteristic locations. In the municipality of Zakopane, the town center is such characteristic location. The map in figure 9 shows the relationship between the level of unit prices and the distance from the city center. As a result of map analysis, it was found that the center of Zakopane is located at the intersection of ul. Krupówki and ul. Kościuszki. In order to present the relationship studied, 6 ring-shaped zones of $1 \mathrm{~km}$ in width were designated around the point indicating the town center. For each zone, the average unit transaction price was calculated. Zone I - the central one, is the zone of the highest level of average unit prices. As the distance from the center increases, the average unit prices decrease, all the way to Zone IV. Zone V has similar average unit prices as Zone III. The lowest prices were found in Zone VI.

Table 3 shows the average unit price in the respective zones of all undeveloped land properties. Fairly large diversity of the prices between zones I, II and III and V and VI can be noticed. The unit prices in the center are more than twice higher than in the zone located between $1 \mathrm{~km}$ and $2 \mathrm{~km}$ from the center. The relationship of prices between the zones II and III is similar. It is an indication of very high prices for $1 \mathrm{~m}^{2}$ of undeveloped land in the town center, which costs almost 820 PLN, and of a rapid decline in prices with the growing distance from the center. When analyzing zones III and IV, a slight decrease of the average unit price can be seen compared to the previously mentioned zones. Zone VI is the most peripheral zone, where the average unit price is PLN $64 / \mathrm{m}^{2}$.

Table 3. The average unit price of undeveloped land properties in the Municipality of Zakopane depending on their distance from the center

\begin{tabular}{|c|c|c|}
\hline Zone number & $\begin{array}{c}\text { Distance from the } \\
\text { centre }[\mathrm{km}]\end{array}$ & $\begin{array}{c}\text { Average unit price } \\
\text { [PLN] }\end{array}$ \\
\hline I & $0-1$ & 816 \\
\hline II & $1-2$ & 320 \\
\hline III & $2-3$ & 129 \\
\hline IV & $3-4$ & 113 \\
\hline V & $5-6$ & 121 \\
\hline VI & $6-7$ & 64 \\
\hline
\end{tabular}

\section{CONCLUSIONS}

The unit prices of transaction properties were used to create a spatial distribution map of transactions together with the level of unit prices of the properties sold. This map provides the greatest amount of information about the market studied. With the help of this map, the areas with the highest unit prices can be indicated, which are the following: Śródmieście, Zamoyskiego, Skocznia, which is the town center of Zakopane. The lowest unit prices were noted in the areas located in the north-eastern part of the municipality. Valuable information about the market is also provided by the diagram map. The diagram map shows the intensity of transactions of undeveloped land in the years 2011-2015 in specific areas and the bar charts show the number of transactions depending on the type of land property in a given area. The small number of transactions in the area of Gubałówka or within the vicinity of Tatrzański National Park indicates that the parcels in the locations that are very attractive in terms of views or natural features are rarely traded. The relationship between the average unit price and the distance from the town center was shown. The location is the fundamental characteristic of real estate properties. Studying the spatial distribution of the quantitative real estate data and the presentation of the results in the form of maps seems to be the best way of visualization of the information about this market.

\section{Acknowledgments}

This publication is funded by the Polish National Agency for Academic Exchange under the International Academic Partnerships Programme from the project "Organization of the 9th International Scientific and Technical Conference entitled Environmental Engineering, Photogrammetry, Geoinformatics - Modern Technologies and Development Perspectives".

\section{REFERENCES}

1. Białas W., Budarka, 1991. Zakopane four hundred years of history (in Polish), Wydawnictwo KAW, t. I, Kraków.

2. Bitner A., 2015. The method of trends combination for the real estate market (in Polish), Przegląd Geodezyjny (2), p. 3-5. 
3. Bitner A., 2011. The quality of the real estate price increase index based on the analysis of pairs of similar estates (in Polish), Acta Scientiarum Polonorum - Administratio Locorum, 10(4), 5-13.

4. Całka B., Bielecka E. 2014. Average housing value map: the case study of housing primary market in Siedlce (in Polish). Roczniki Geomatyki, XII, 4(66), 379-387.

5. Cymerman R. Fiedorowicz-Kozłowska E. Kurowska K. Marcinkowska I. Nowak-Rząsa M. Szczepańska A. Tyszko L. 2000. Real estate valuation and environmental protection (ecological considerations in real estate valuation) (in Polish). Educational materials, series: Nieruchomość No 7/2000. Publisher: Educaterra

6. Kim K. 2019. The Value of Name in the Housing Market: Evidence from South Korea's New Address System. Journal of Real Estate Research, 41(4), 669-691

7. Kovacs, K.F. 2012. Integrating property value and local recreation models to value ecosystem services from regional parks, Landsc. Urban Plan., 108, 79-90.

8. Kraak M.-J., Ormeling F., 2010. Cartography: visualization of spatial data, 3rd edition., Pearson Education Ltd, London. ISBN: 978-0-273-72279-3

9. Kuchcik M., Milewski P. 2018. Air pollution in Poland - condition, causes and effects (in Polish). Studia KPZK, t. 182, p. 341-364, PAN Warszawa, ISSN 0079-3507.
10. Liebelt V., Bartke S. Schwarz N. 2019. Urban Green Spaces and Housing Prices: An Alternative Perspective, Sustainability, 11, 3707

11. Maguire D. J., Batty M., Goodchild M. F., 2005. "GIS, spatial analysis, and modeling”, ESRI Press

12. Miazek P. 2017. Tourism as an aspect of the Tatra Mountains National Park's activity (in Polish). Workshops on Geography of Tourism 1(8), Publisher: Lodz University, Lodz, p. 81-92

13. Mika M. 2017. Interoperability cadastral data in the system approach. Journal of Ecological Engineering. 18(2), 150-156

14. Pardo-Garcia C., Coll-Serrano V., Rausell-Köster P., Pérez Bustamante-Yábar D., 2018. Cultural attitudes and tourist destination prescription, Annals of Tourism Research Volume 71, 59-61

15. Pochwatka P., Teterycz T., Litwin U., Bitner A., 2017. Cartographic visualization in the real estate market investigation with the use of GIS tools. IEEE publication: 2017 Baltic Geodetic Congress (Geomatics), DOI: 10.1109/BGC.Geomatics.2017.53

16. Spallek W., 2011. History of statistical data visualization methods, in: The main problems of modern cartography (in Polish). Application of statistics in GIS and cartography. Edited by W. Żyszkowska i W. Spallek. University of Wroclaw, Wroclaw, str. 7-35

17. Stanek L. 2016. The spatial development of undeveloped real estate in the Wrocław district. Journal of Ecological Engineering. 17(4), 203-208 